\title{
Consumer-Driven Profit Maximization in Broiler Production and Processing
}

Ecio de Farias Costa ${ }^{1}$

Jack E. Houston ${ }^{2}$

Resumo - Um aumento na ênfase dada ao mercado de consumidores de carne de frango e modelos de maximização de lucros na produção de frangos de corte geram resultados que diferem daqueles obtidos em modelos tradicionais de maximização de lucros. Esta metodologia revela que a adoção de step-pricing e considerando opções de mercado (exemplos de resposta às preferências de consumidores) afetam os níveis ótimos de formulação de rações e os tipos de produção de frangos de corte que geram uma lucratividade máxima. A adoção de step-pricing atesta que maiores lucros podem ser obtidos para pesos-alvo somente se preços-prêmio para produtos processados de carne de frango forem contratados.

Palavras-chave:decisões do produtor, opções de mercado, preferência do consumidor, step-pricing.

Abstract - Increased emphasis on consumer markets in broiler profitmaximizing modeling generates results that differ from those by traditional profit-maximization models. This approach reveals that the adoption of step pricing and consideration of marketing options

1 Professor de Economia at UFPE- Ph.D. em Economia Agrícola, University of Georgia,2001E-mail: ecio@yahoo.com

2 Professor de Economia Agrícola- University of Georgia- Ph.D em Economia Agrícola, Washington State University, 1986. E-mail: jhouston@ agecon.uga.edu 
(examples of responsiveness to consumers) affect the optimal feed formulation levels and types of broiler production to generate maximum profitability. The adoption of step pricing attests that higher profits can be obtained for targeted weights only if premium prices for broiler products are contracted.

Key Words: consumer preferences, processor decisions, marketing options, step pricing.

\section{Introduction}

Vertically integrated chains of production in the broiler industry make determination of profit-enhancing decisions perplexing. Ascertaining profits in broiler production is complex, because the production and processing involve many steps, ranging from hatchery to production using formulated feeds to processing in the plants and to distribution onwards. Efficient organization and utilization of resources will produce not necessarily the heaviest, but the most profitable, broilers. The retail market is consumer-driven, and thus it is important for the processors to meet the specific characteristics desired by consumers for product size and quality most profitably.

The retail market demands specific finished products that are not al ways the most technically efficient results of production processes. Fast food restaurants, for example, only want breast meat that falls into the weight that will fit in their sandwich bread. This smaller weight bird, however, may not be as profitable to a broiler processor who could make more profit by feeding for longer periods or feeding a low-cost feed that will not give the desired weight or fat content. Further, the retail market pays a premium price for meeting the specifications of the products they expect from broiler processors. Using the specifications for desired weight and the premium prices they attract, a profit maximization model must show efficient ways of meeting such distinctive products yet resulting in profitability for the firm. Modeling consumer-driven broiler production to obtain maximum profits requires the adoption of marketing requirements that induce efficient production. This study analyzes the adoption of step-pricing and marketing options on profitable broiler production. 
Higher prices are paid to processed parts that meet specifications of the retail market, and this premium price concept is termed step pricing. Such specifications can be used for selling chicken parts that target a weight range that the consumer prefers, for example. The concept of marketing options is based on the premise that broiler processors must decide at what processing level they want to sell their products; i.e., whether to process chickens into whole carcasses, or to further process them to sell as cut-up parts, seasonally adjusting to the market. The prices paid differ as to the level of processing, and the production process is also directly influenced by the marketing decision process. After the steppricing and marketing options are chosen, it is necessary to integrate this information into the decision model to determine the most efficient feed formulation and production process to yield targeted products.

The proper feed ration is formulated according to prior information on step-pricing and marketing options, but it will also be formulated according to the prices and availability of nutrient sources. Other factors also play a role in the broiler model composition. For example, it is necessary to factor in the gender percentage of the chicks, temperature and size of the house, and other factors influencing the optimal production of the targeted product.

The profit-maximizing analysis for consumer market-driven broiler production and processing decisions presented in this study is composed of three stages. First, broiler response functions over experimental feeding data are estimated to determine the broiler production functions to be used in the profit maximization model. Second, results obtained from the production scenarios are used for profitability analysis of the two marketing options: selling broilers processed as whole carcass vs. selling broilers processed as cut-up parts. Finally, a step-pricing analysis of outputs generated by the two marketing options determines premium prices (stepprices) that are as profitable as baseline scenarios for target weights determined by the retail market in response to consumer preferences.

The main objective of this study is then to simulate the adoption of consumer preferences in a profit maximization model, through the adoption of step-pricing in different marketing scenarios. The advantages of the adopted methodology are that broiler integrators will face a more efficient production system that will yield in more profitable production processes. 


\section{Related Literature}

\section{Profit Maximization and Cost Minimization Broiler Models}

Starting in the 1950's with the widespread adoption of mathematical programming, interest in feed formulation was renewed. For decades, the major objective to be attained in optimal broiler production was to minimize the cost of feed, and little consideration was allocated to other determinants of profitability. Least-cost rations minimize the cost of diets, given a certain set of ingredients and their nutritional content. An important assumption of least-cost formulated diets is that every unit of a least-cost formulated ration has the same productivity regardless of ingredient sources (Allison and Baird, 1974).

The adoption of simple cost minimization does not account for differentials in productivity among input sources; e.g., broiler performances in experimental trials of those birds fed peanut meal protein vs. those fed soybean meal (SBM) protein have been shown to differ significantly (Costa et al., 2001). On the other hand, the adoption of profit maximization techniques later in the 1990's has taken into consideration the productivity aspects of economically efficient broiler production. Few models have been developed thus far, and they differ in their approaches to the problem.

Gonzalez-Alcorta et al. (1994) developed a profit maximization model that uses nonlinear and separable programming to determine the precise energy and protein levels in the feed that maximize profit. Their model is distinguished by the assumption that body weight is not fixed at a predetermined level. Feed cost is not determined by least cost feed formulation. Rather, feed cost is determined as a variable of the profit maximization model in a way similar to that described in Pesti et al. (1986). Gonzalez-Alcorta et al. (1994) conclude that setting energy and protein levels that vary with output and input prices can raise profit compared to fixed diet levels of energy and protein based on previous nutritional guidelines.

Costa et al. (2001) developed a 2-step profit maximization model that minimizes feed cost and maximizes profit in broiler production. Their model indicates the optimal average feed consumed, feed cost, live and processed body weight of chickens, as well as the optimal length 
of time that the broilers must stay in the house and other factors, for given temperature, size of the house, costs of inputs and outputs and for certain, pre-determined protein level, source, and processing decisions. They conclude that peanut meal can be more profitable than SBM for growing birds to be processed and sold as whole carcasses.

The analysis conducted in our study differs from Costa et al. (2001) by developing a decision model that allows for a single, feedback procedure that is determined by the consumer-oriented price signals. This construction not only generates processing alternatives for selling whole carcass and cut-up parts, but the model also determines the marketing option that is the most profitable, given expected product prices. The solutions allow for adjustment of the production to given targeted weights and premium prices for broiler products in the procedure, called step pricing, as already mentioned. An important feature of this model is that the processing decision takes place only after expected prices of inputs and outputs are determined. The prices of outputs are determined by consumers in the market place.

This study uses data obtained from an experiment conducted at the University of Georgia ${ }^{3}$, which uses trials conducted for the collection of information on live body weight, feed consumption and weight of processed parts. This data set, which contains productivity information, is used to estimate the production response functions that are used in the profit maximization model of this study.

\section{Model Description}

A brief description of the model follows ${ }^{4}$. The objective function to be optimized is:

3 Feed composition and feeding level experiment was conducted by the Poultry Science Department at the University of Georgia. The experiment consisted of using four different levels of protein $(17 \%, 20 \%, 23 \%$, and $26 \%$ ) using SBM as protein source to feed broiler chickens until 42 days and collecting body weight, feed consumed and weight of processed parts. For more detailed information, contact the authors.

4 The objective of this manuscript is not to discuss the description and functionality of the proposed model, but the application of the same to consumer-oriented market profitability decisions. For a more detailed description, see Costa (2001). 
$\operatorname{Max} \Pi=\left[\left(D P_{B W} * B W\right)-\left(P_{F C} * F C\right) * I\right] / t$

subject to (among the full set of constraints):

$$
\begin{aligned}
& P_{F C}=P_{F}+D E L \\
& P_{F}=\sum_{t=1}^{n} P_{t} * X_{t} \\
& B W=f\left(F C, F C^{2}, P R, P R^{2}, F E\right) \\
& F C=f\left(t, t^{2}, P R, P R^{2}, F E\right) \\
& I=\left(1+\frac{r}{365}\right)^{t}
\end{aligned}
$$

for marketing options,

$$
\begin{aligned}
& D P_{B W}=\frac{L V_{k}}{B F} \\
& L V_{k}=B F *\left[(1-D O A) * A D P_{k}+D O A * P_{D O A}\right] \\
& A D P_{k}=\frac{\sum_{l}\left(w_{l} *\left(P_{l}-P R O_{l}-C A T_{l}\right)\right.}{B W} \\
& w_{l}=f\left(B W, P R, P R^{2}, F E\right)
\end{aligned}
$$

and, for the step-pricing,

$$
\begin{aligned}
& \text { If } w_{l}=T W_{l} \text { Then } A D P_{k}=\frac{\sum_{l}\left(w_{l} *\left(T P_{l}-P R O_{l}-C A T_{l}\right)\right.}{B W} \\
& \text { Otherwise } A D P_{k}=\frac{\sum_{l}\left(w_{l} *\left(P_{l}-P R O_{l}-C A T_{l}\right)\right.}{B W}
\end{aligned}
$$


In the objective function (Equation 1), maximum profit per bird per day $(\Pi)$, is defined as a function of derived price $\left(D P_{B W}\right)$, live body w eight (BW), cost of feed consumed $\left(P_{F C}\right)$, feed consumed ( $\left.F C\right)$, interest cost (I), and feeding time (t). Due to the objective function's specification, the constraint set includes a number of equations (nutrition constraints, and other constraints in the model) that are not specifically mentioned in this manuscript. However, the most relevant constraints that allow for a direct comparison between the two marketing options and step-pricing analyses are described next. Cost of feed consumed $\left(P_{F C}\right)$ includes feed delivery cost (DEL) and the least cost feed $\left(P_{F}\right.$, Equation 2$)$. The least cost feed function (FC) minimizes the cost of feed for pre-determined ingredients $\left(X_{i}\right)$ and their prices $\left(P_{i}\right)$ and is determined by the optimization process (Equation 3 ). Live chicken body weight (BW) is determined by feed consumed (FC), feed consumed squared $\left(F C^{2}\right)$, protein level $(P R)$, protein level squared $\left(P R^{2}\right)$, and an intercept shifter for female chickens (FE, Equation 4). The coefficients of the BW function are determined by ordinary least squares (OLS) on experimental data. Feed consumed (FC) is determined by feeding time $(t)$, feeding time squared $\left(t^{2}\right)$, protein level $(P R)$, protein level squared $\left(P R^{2}\right)$, and an intercept shifter for female chickens (FE, Equation 5). Interest cost (I) is determined as a function of the annual interest rate ( $r$ ) figured daily (dividing by 365 days) and the number of days necessary to grow broilers ( $t$, Equation 6).

The constraints in the model that introduce alternative marketing options are presented in Equations 7-10. The marketing option varies according to the marketing option $\mathrm{k}$ (whole carcass or cut-up parts marketing option). Derived price ( $D P_{B W}$, Equation 7$)$ is a function of live value of birds delivered to the plant $\left(\mathrm{LV}_{\mathrm{K}}\right)$ divided by the number of birds that finished the production process (BF). $L_{\mathrm{K}}$ (Equation 8) is a function of $\mathrm{BF}$, and average values of the weights of processed part $k$ $\left(A D P_{k}\right.$ Equation 9) depend on the processed weight $\left(w_{k}\right)$.

Equation 10 is estimated as processed weight, $w_{1}$, of each part I derived from a live bird $(I=W C$ for whole carcass, BR for skinless boneless breast weight, TE for tenderloin, LQ for leg quarters, WI for wings, FP for fat pad, and RC for rest of chicken for the cut-up parts processed broiler). The sum of all processed parts must be equal to the 
live weight of the bird (plus offal and giblets). Each equation is estimated as a function of live bird weight (BW), protein level (PR), protein level squared $\left(P R^{2}\right)$, and gender of birds (FE). The coefficients are estimated by OLS on experimental data.

We modify the model for the adoption of the step-pricing constraint by setting a further constraint on the targeted weight for the processed part that is to be produced. Equation 11 presents the constraint that is added to the model. The target weight of part I, TW ${ }_{1}$, is determined by the consumer retail market and must be met by the processor by contracting with buyers of such weight-targeted processed parts. If the model finds the target weight as an optimal answer, it uses the premium price, $\mathrm{TP}_{\mid}$, as a step-price in the model. If not, the model uses the lower, general product price, $\mathrm{P}_{1}$.

The linear program model is simulated using a built-in linear program analysis package in Microsoft Excel (2000), Solver. Each simulation is recorded and comparison analyses are conducted among the optimal results for every scenario. Step-prices are also incorporated in the simulations to obtain the targeted weights. The optimal answers and comparison analyses are presented next, as well as the estimated production responses that are estimated using SAS (1996).

\section{Estimated Production Responses}

Production Equations 4, 5 and 10 are estimated by OLS and presented next (Tables 1 and 2). Table 1 displays the estimated coefficients of Equations 4, 5 and 10 (only for estimation of carcass weight in 10). Live bird weight (BW) increases at a decreasing rate with respect to feed consumed (FC) and protein level (PR), while feed consumed increases at an increasing rate with respect to feeding time $(t)$ and increases at a decreasing rate with respect to protein level (PR). Weight of whole carcass $\left(\mathrm{W}_{\mathrm{wc}}\right.$ ) increases at a decreasing rate with respect to protein level (PR). Estimated coefficients of Equation 10 (for skinless boneless breast, tenderloin, leg quarters, and wings weights) are shown in Table 2. W eights of skinless boneless breast, tenderloin, leg quarters, and wings ( $\mathrm{W}_{\mathrm{BR}}, \mathrm{W}_{\mathrm{TE}}, \mathrm{W}_{\mathrm{LQ}}$, and $\mathrm{W}_{\mathrm{W}}$, respectively) increase at increasing rates with respect to PR. These results concur with those of Pesti and 
Smith (1984) that show that production responses of broilers to dietary energy and protein levels show diminishing marginal returns.

Prices of inputs and outputs are collected for the profit maximization analysis. The prices data include prices of ingredients available for the ration formulation, including major feedstuffs and synthetic amino acids that supplement the deficiencies of major sources, and prices received in Georgia (or the Southeast of the United States, which is responsible for the largest production in the world) for the outputs considered in the analysis as well as other costs considered in the analysis. Other inputs to the model include average temperature and size of the broiler house.

Table 1 - Estimated Body W eight, Feed Consumed, and Carcass Weight for Broilers

\begin{tabular}{|c|c|c|c|}
\hline Variable & Body Weight & Feed Consumed & Carcass W eight \\
\hline Intercept & $\begin{array}{l}-1.698^{* *} \\
(0.542)\end{array}$ & $\begin{array}{r}-1.107 \\
(0.854)\end{array}$ & $\begin{array}{l}-409.280^{* *} \\
(179.164)\end{array}$ \\
\hline $\mathrm{FC}$ & $\begin{array}{c}0.692^{* *} \\
(0.034)\end{array}$ & -- & -- \\
\hline $\mathrm{FC}^{2}$ & $\begin{array}{c}-0.043^{* *} \\
(0.007)\end{array}$ & -- & -- \\
\hline $\mathrm{T}$ & --- & $\begin{array}{r}0.004 \\
(0.017)\end{array}$ & --- \\
\hline $\mathrm{T}^{2}$ & --- & $\begin{array}{c}0.002^{* *} \\
(0.001)\end{array}$ & --- \\
\hline BW & -- & -- & $\begin{array}{c}0.753^{* *} \\
(0.013)\end{array}$ \\
\hline PR & $\begin{array}{c}0.158^{* *} \\
(0.050)\end{array}$ & $\begin{array}{r}0.086 \\
(0.071)\end{array}$ & $\begin{array}{r}25.523 \\
(17.158)\end{array}$ \\
\hline $\mathrm{PR}^{2}$ & $\begin{array}{l}-0.003^{* *} \\
(0.001)\end{array}$ & $\begin{array}{r}-0.002 \\
(0.002)\end{array}$ & $\begin{array}{r}-0.546 \\
(0.397)\end{array}$ \\
\hline FE & $\begin{array}{c}-0.061^{* *} \\
(0.017)\end{array}$ & $\begin{array}{l}-0.240^{* *} \\
(0.024)\end{array}$ & $\begin{array}{r}7.760 \\
(7.890)\end{array}$ \\
\hline $\begin{array}{l}\overline{\mathrm{R}}^{2}-- \\
\mathrm{N}\end{array}$ & $\begin{array}{c}0.9899^{-}- \\
72\end{array}$ & $\begin{array}{r}-{ }^{-}-\overline{9} \overline{9} \overline{46} \\
72\end{array}$ & $\begin{array}{c}-\overline{0} . \overline{9} \overline{0} 3 \\
144\end{array}$ \\
\hline
\end{tabular}

Standard errors are in parentheses.

* Indicates parameter estimate is statistically significant at the 0.10 level.

** Indicates parameter estimate is statistically significant at the 0.05 level.

Body Weight and Feed Consumption functions are estimated in $\mathrm{kg}$. Carcass Weight function is estimated in grams. 
Table 2 - Effects of Live Weight, Protein Level and Gender of Bird on Weights of Cut-up Parts of Broilers

\begin{tabular}{|c|c|c|c|c|}
\hline Variable & Breast & Tenderloin & Leg Quarters & Wings \\
\hline Intercept & $\begin{array}{c}-221.257^{*} \\
(118.450)\end{array}$ & $\begin{array}{l}-\mathbf{8 0 . 8 7 6}{ }^{* *} \\
(26.624)\end{array}$ & $\begin{array}{r}\mathbf{- 2 9 . 0 8 8} \\
(136.867)\end{array}$ & $\begin{array}{l}-\mathbf{5 0 . 0 2 3} \\
(44.314)\end{array}$ \\
\hline BW & $\begin{array}{c}0.184^{* *} \\
(0.008)\end{array}$ & $\begin{array}{c}0.044^{* *} \\
(0.002)\end{array}$ & $\begin{array}{c}0.336^{* *} \\
(0.010)\end{array}$ & $\begin{array}{c}0.083^{* *} \\
(0.003)\end{array}$ \\
\hline PR & $\begin{array}{r}12.058 \\
(11.385)\end{array}$ & $\begin{array}{c}4.530^{*} \\
(2.560)\end{array}$ & $\begin{array}{r}-0.264 \\
(13.155)\end{array}$ & $\begin{array}{r}4.384 \\
(4.259)\end{array}$ \\
\hline $\mathrm{PR}^{2}$ & $\begin{array}{r}-0.234 \\
(0.263)\end{array}$ & $\begin{array}{r}-0.083 \\
(0.059)\end{array}$ & $\begin{array}{r}-0.008 \\
(0.304)\end{array}$ & $\begin{array}{r}-0.100 \\
(0.098)\end{array}$ \\
\hline FE & $\begin{array}{l}13.237^{* *} \\
(5.216)\end{array}$ & $\begin{array}{c}6.119^{* *} \\
(1.172)\end{array}$ & $\begin{array}{l}-17.239^{* *} \\
(6.027)\end{array}$ & $\begin{array}{r}0.835 \\
(1.951)\end{array}$ \\
\hline $\mathrm{R}^{2}$ & $0 . \overline{8} \overline{1} \overline{2}$ & $0 . \overline{8412}$ & $0 . \overline{9} 26 \overline{8}$ & $0 . \overline{87} \overline{8}$ \\
\hline $\mathrm{N}$ & 144 & 144 & 144 & 144 \\
\hline
\end{tabular}

Standard errors are in parentheses.

* Indicates parameter estimate is statistically significant at the 0.10 level.

** Indicates parameter estimate is statistically significant at the 0.05 level.

All functions are estimated in grams.

\section{Model Interactions, Marketing Options and Step-pricing Analyses}

Our model is first used to estimate the profitability of two baseline scenarios, where broilers are produced and sold after being processed into whole carcasses or into cut-up parts. Thus, the baseline scenarios are analyzed for the collected data on prices of inputs and outputs. Initially, comparisons are made directly between whole carcass marketing option and cut-up parts marketing option results for each selling alternative. Lastly, targeted weights are applied to the model in order to simulate premium prices and their profitability through the step-pricing concept. Optimal solution sets report broiler weights, feed consumption, feeding time, and feed composition that maximize profit under certain production function estimation, marketing option, and input/output prices. All optimal formulated rations meet all nutrient requirements from the National Research Council (NRC, 1994) for the nutrient requirements for poultry production and replicate the industry standards. The results obtained from the interaction of the program formulate an optimal grow-out feeding ration. Each optimized ration 
is fed to broilers for an optimal number of days in order to obtain an optimal weight that is to be processed and sold to a specific market, given the prices of outputs and ingredients and other costs integrated in the model, as illustrated by the case scenario in Figure 1.

Assume in Figure 1 that the current price of whole carcass is higher at a certain time of the year because consumers are demanding relatively more whole carcass meat (roasting). Prices of outputs and inputs are then entered in the model, which uses previously entered information and relationships on production and returns to carcass weight products of broilers, nutrient requirements determined by the NRC (1994), size of the house, temperature, chicks gender information, and other production costs. The model incorporates these two aspects of the input and output markets, and model results suggest that the processor grow and process broilers into whole carcass. The optimal solution set that is generated by the model goes first to decisions in the broiler house, where optimal feed composition and optimal feeding time are set to deliver live body weight of birds. The body weight produced in the broiler house is transmitted to the processing plant, where the profit-maximizing carcass weight is the outcome.

A second output solution set generated by this model is represented in Figure 1 by the dotted lines. The dotted lines show the option in the model that represents the setting of a targeted weight by the retail market that is rewarded by a step-price paid to processors. As consumer demand increases for whole carcass, the whole carcass weights that are targeted are conformable to the weights retailers sell in their market. As a reward for requiring such weight for the output, retailers provide a step-price to the poultry processor, who redefines the process of production to attain such target weight. This redefinition of targeted products involves using a different length of time of production as well as a different combination of inputs to attain the desired weight efficiently. 
Figure 1 - Example of Production and Processing Decision Schematic for Integrated Broiler Profit Maximization.

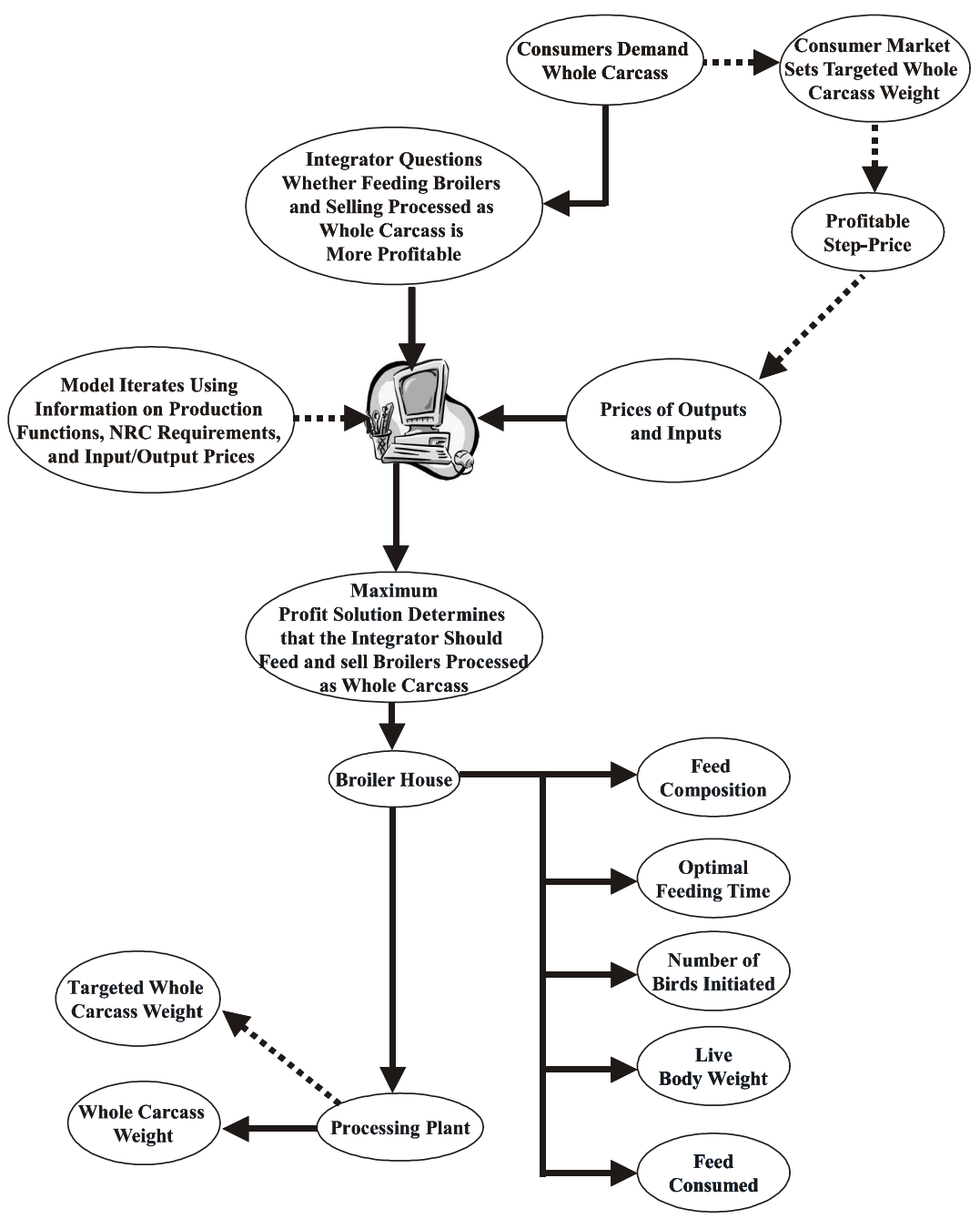

Selling Broilers According to Marketing Options - Baseline Scenarios

Results demonstrating the most-profitable production process for selling broilers that are processed into whole carcass or selling cut-up parts are presented in Table 3. Results indicate the baseline scenarios where feeding formulations are most profitable for the production of broilers that are 
processed and sold as whole carcass or cut-up parts markets under the prices of inputs and outputs observed for the time period chosen. Although processing broilers into cut-up parts generates the most profitable marketing option, results can and will differ for different price circumstances.

The NRC (1994) recommends that the protein level in the diets used for broilers in the grower phase, from 3 to 6 weeks, should be equal to $20 \%$. However, the formulated feeds in this model present protein levels above the recommended level. Comparative results also indicate that a longer feeding time and more feed consumed are allocated to produce a heavier bird for the cut-up parts marketing option than for the whole carcass marketing option. Cut-up parts have an aggregated value that is higher than the value of whole carcass. Therefore, a longer feeding cycle and more feed consumed can be used to seek a higher profitability in terms of net returns per bird per day.

Table 3 - Scenarios Obtaining Maximum Profitability in Broiler Production under Consumer-determined Marketing Conditions

\begin{tabular}{lccc}
\hline Variable & Unit & Whole Carcass & Cut-up Parts \\
\hline Protein Level & $\%$ & 23.12 & 23.92 \\
Feeding Time & days & 39.78 & 40.07 \\
Bird Weight & $\mathrm{lb}$ & 5.03 & 5.10 \\
Feed Cost & cents/lb & 7.51 & 7.61 \\
Feed Consumed & $\mathrm{lb} / \mathrm{bird}$ & 7.96 & 8.04 \\
Feed Conversion Ratio & $\mathrm{Ib} / \mathrm{lb}$ & 1.58 & 1.58 \\
Profit (П) & cents/bird/ day & $\mathbf{1 . 5 1}$ & $\mathbf{2 . 5 9}$ \\
Derived Price & cents/lb & 29.01 & 33.29 \\
Broiler House Revenue & /house/ period & 8,731 & 19,622 \\
Carcass Weight & $\mathrm{lb}$ & 3.55 & -- \\
Skinless Boneless Breast Weight & $\mathrm{Ib}$ & -- & 0.790 \\
Tenderloin Weight & $\mathrm{lb}$ & -- & 0.178 \\
Leg Quarters Weight & $\mathrm{lb}$ & -- & 1.625 \\
Wings Weight & $\mathrm{lb}$ & -- & 0.420 \\
\hline
\end{tabular}

\section{Step-Pricing Analysis for Targeted Weight of Whole Carcass and Cut-up Parts}

Profitability is next related to optimally producing broilers to target weights; i.e., weights determined by the retail market in response to consumer preferences require that a new constraint be added to the 
Consumer-Driven Profit Maximization in Broiler Production and Processing

model that sets carcass or cut-up parts weights equal to a desired level (as indicated in Equations 10 and 11, and Figure 1). This desired level is determined by the retailers, who learn from their own consumption studies what processed weights of carcass or cut-up parts their consumers prefer. Thus, a poultry processor must meet certain weight levels in order to induce a premium price from the retailers. As an example, fast food restaurants require that the w eight of chicken breasts fall within a tight range that will fit in the standard sandwich bread. They will pay a premium price (or step-price in our model) to the processor that sells them a product meeting these specifications.

Sample data on carcass, skinless boneless breast, tenderloin, leg quarters and wings weights were collected from a food retailer, and the average weights for each processed part were assumed to be the target weights. All averaged weights reported by the food retailer are higher than the optimal levels indicated in the previous analyses of the baseline scenarios conducted with current market prices and no target weights set as constraints. Despite those differences, the next analyses show target weights and the corresponding step-prices that make the production process as profitable as the baseline solutions for the various marketing options.

\section{Step-Pricing Analysis on Whole Carcass}

In the step-pricing analysis on the whole carcass market, a carcass target weight of $3.99 \mathrm{lbs}$. (against baseline levels of $2.90 \mathrm{lbs}$.) is set. Initially, in the first column of Table 4, the target weight constraint is applied to broilers using the same market price as the result presented in Table 3, analysis for whole carcass. Profit levels decline for attaining that target weight, showing that if no step-price is applied, the target weight generates economic inefficiency. Protein level, feeding time, live w eight, feed cost, and feed conversion ratio all increase as the target weight is considered. Further interactions of the model, increasing the price of whole carcass above market level to obtain higher profits, show that if one seeks to achieve a profit level equal to the baseline profit reported in Table 3 and also a target weight of 3.99 lbs., then there must be an increase in the price of whole carcass on the order of $2.44 \%$. 


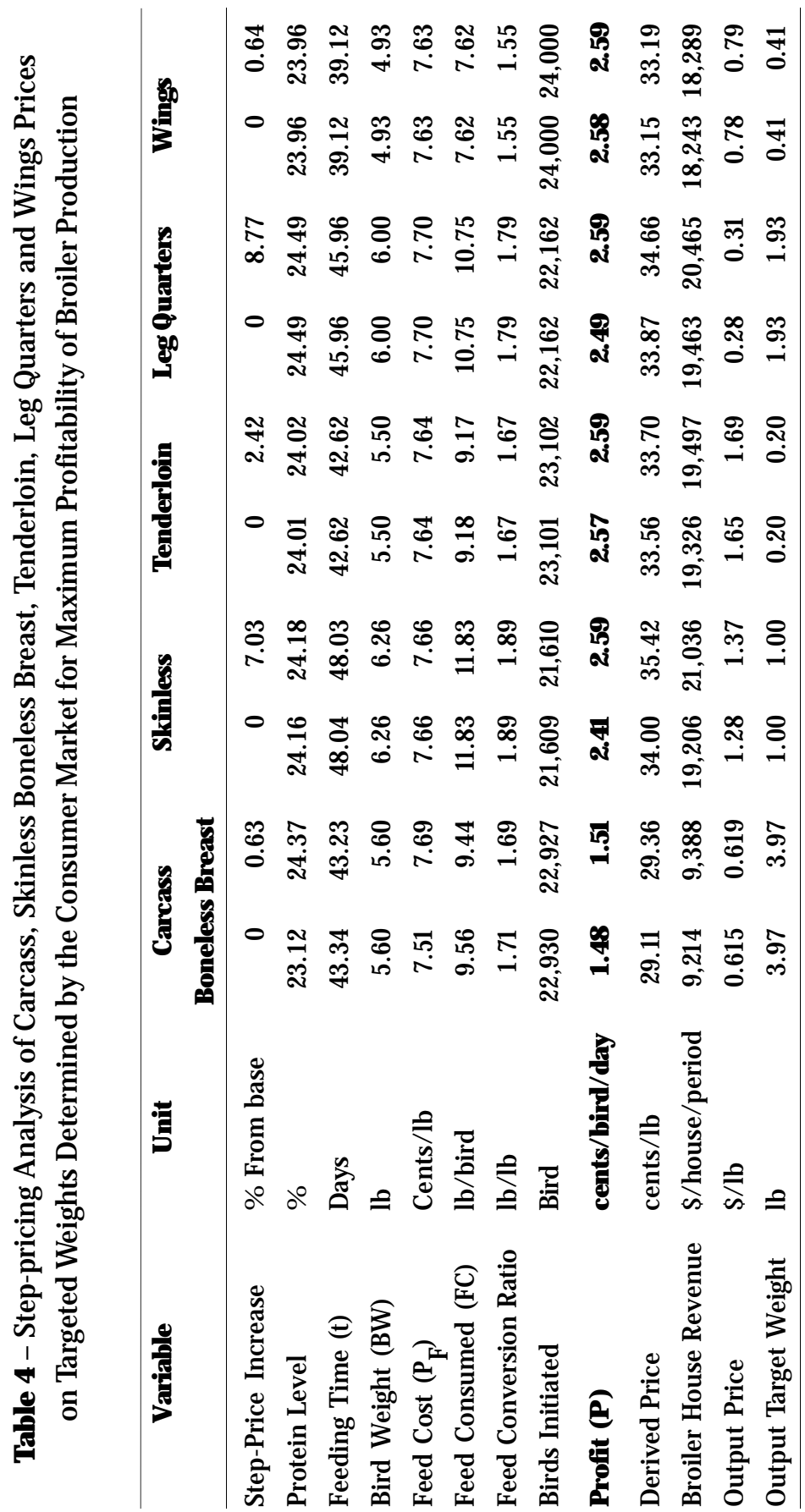




\section{Step-Pricing Analysis on Cut-up Broiler Parts}

The step-price analysis for target weights is next applied to cut-up processed parts: skinless boneless breast, tenderloin, leg quarters, and wings. According to sample data collected from a food retailer, their target weights are $1.00,0.20,1.93$, and $0.41 \mathrm{lbs}$., respectively. The sampled average weights from the food retailer are again higher than the baseline optimal solutions, with exception of the weight of wings, which is lower than the baseline solution. In other words, the optimal solution obtained in the model interaction at current prices indicates that the weight of skinless boneless breast, tenderloin, and leg quarters are lower (and for wings, higher) than the average weights reported by the food retailer.

Columns 3-10 of Table 4 exhibit the premium price analyses on targeted skinless boneless breast, tenderloin, leg quarters, and wings weights. Target weights drive profitability down for all processed parts when compared to the baseline solutions if no step-price is applied to the model. In order to attain the same profitability level of production as reported in Table 3, increases in the prices of cut-up parts are necessary. The prices of skinless boneless breast, tenderloin, leg quarters, and wings would have to increase by $7.03 \%, 2.42 \%, 8.77 \%$, and $0.64 \%$, respectively, to match profitability levels recorded in the baseline solutions. Notice that the protein level, feeding time, and live bird weight are higher for the targeted w eights of processed parts, with the exception of wings weight (that is lower), than the baseline solutions. This response is again due to more inputs being allocated when there is an extra reward expected as a step-price to induce the altered efficient production of broilers.

\section{Conclusions}

The profit-maximization model developed in this work interactively generates optimal solutions for marketing options that process and sell broilers in the carcass and cut-up parts markets. Feeds formulated for all optimal solutions meet all NRC requirements for nutrient composition of feed rations, but the protein levels indicated by this model are 
substantially above the average levels reported in the industry and range from $23 \%$ to just less than $25 \%$ protein level in the diet.

Comparison between marketing options indicates that profits are higher for the cut-up parts marketing option than for the whole carcass market option, because more value is added to broilers processed into cut-up parts. In the whole carcass marketing option, birds are fed for shorter feeding times than are broilers in the cut-up parts marketing option. Both the average live body weight and feed consumed are lower for broilers produced in the whole carcass marketing option than for broilers produced in the cut-up parts marketing option. Adoption of target weights represents a decline in profits, if no step-price is applied to induce the adoption of target weights. However, as step-prices are employed, profits can be increased for both marketing options to profit levels in the baseline scenarios. Negotiation must take place between retailers and processors when deciding what step-price should be adopted for different marketing options. Broiler processors must incorporate all steps of their production and processing into the decision-making and agree on contract terms that represent efficient allocation of their inputs. This should include seasonal and other market-related information, especially as pertains to product mix in each cycle of production. Retailers must recognize that step-prices may be required to induce special requests for targeted weights that are expected from poultry processors. Determining what the terms of negotiation should be is beyond the scope of this study, but the findings generated by this comprehensive profit-maximizing model may serve as a promising start. The behavior of broiler processors in Brazil and the United States must change to incorporate the concepts of step-pricing and consumer preferences in their production and processing. By doing that, their profitability in broiler production and processing will increase considerably.

On the other hand, the impacts of this research results for broiler growers must be further discussed. As presented, the results may indicate lower optimal weights and lower production processes that may result in higher number of flocks' rotations for growers. Growers and integrators must also negotiate how the extra profits generated by this efficiency gain will be distributed among themselves. Therefore, new ways of evaluating the grower's production behavior must be determined. 


\section{References}

ALLISON, J. R., and D. M. BAIRD. 1974. "Least-cost Livestock Productions Rations." Southern J ournal of A gricultural Economics 6: 41-45.

COSTA, E. F. 2001. Economic Modeling for Optimal Broiler Production and Processing. PhD Dissertation. Department of Agricultural and Applied Economics, University of Georgia.

COSTA, E. F., B. R. MILLER, G. M. PESTI, R. I. BAKALLI, and H. P. EWING. 2001. "Studies on Feeding Peanut Meal as a Protein Source for Broiler Chickens." Poultry Science J ournal 80(3): 306-313.

COSTA, E. F., B. R. MILLER, J. E. HOUSTON, and G. M. PESTI. 2001. "Production and Profitability Responses to Alternative Protein Sources and Levels in Broiler Rations." Journal of Agricultural and Applied Economics 33, 3(December):567-581.

GONZALEZ-ALCORTA, M. J., J. H. DORFMAN, and G. M. PESTI. 1994. "Maximizing Profit in Broiler Production as Prices Change: a Simple A pproximation with Practical Value." Agribusiness: An International J ournal 10:389-399.

MICROSOFT ${ }^{\circledR}$ EXCEL 2000. Copyright ${ }^{{ }^{\circledR}}$ 1985-1999 Microsoft Corporation.

NATIONAL RESEARCH CCOUNCIL (NRC). Nutrient Requirements of Poultry. (9th revised edition). Washington, DC: ®National Academy Press, 1994.

PESTI, G. M., and C. F. SMITH. 1984. "The Response of Growing Broiler Chickens to Dietary Protein, Energy and Added Fat Contents." British Poultry Science J ournal 25:127-138.

PESTI, G. M., R. A. ARRAES, and B. R. MILLER. 1986. "Use of the Quadratic Growth Response to Dietary Protein and Energy Concentrations in Least-cost Feed Formulation." Poultry Science J ournal 65:1040-51.

SAS INSTITUTE INC. SAS ${ }^{\circledR}$ Version 6.10, Cary, NC: SAS Institute Inc. 1996.

Recebido em abril de 2003 e revisto em agosto de 2003. 